\title{
The influence of Transit Area in Public Open Space of Losari Beach Makassar Pavilion on the Activities of Group Visitors
}

\author{
Miftahuljannah $^{\mathrm{a}, *}$, Triyatni Martosenjoyo ${ }^{\mathrm{b}}$, Rosady Mulyadi $^{\mathrm{c}}$ \\ ${ }^{a}$ Architecture Department, Engineering Faculty, Hasanuddin University, Makassar Indonesia. Email: miftahuljannah117zb@gmail.com \\ bArchitecture Department, Engineering Faculty, Hasanuddin University, Makassar Indonesia. Email: triyatni@gmail.com \\ cArchitecture Department, Engineering Faculty, Hasanuddin University, Makassar Indonesia. Email: rosady@unhas.ac.id
}

\begin{abstract}
Urban communities are social beings who have a high level of activity. One of the activities to unwind is a refreshing type of activity. A developing city like Makassar needs open space for the public as a container for community activities, including refreshing activities. The Losari Beach Pavilion is present as a public open space that is visited by the majority of visitors in groups to carry out refreshing activities. This public open space has a space configuration with the design of providing a stopover for activities in several parts of the space. This part of the space looks like overlapping activities so that there is space utilization at the stopover point and part of it becomes unoccupied space. Therefore, this study was conducted to explain the effect that occurs on the stopover space and unoccupied space in this case the unused space based on its function. This study used the descriptive qualitative method. The data collection technique used the behavior mapping method by recording activities and sketches to get an image of the activity pattern carried out by group visitors and then presented in the form of tables, pictures and descriptions. The results of the study found that the transit space as a place of stoping point because of the influence of spatial area, visibility, historical area, iconic elements, social interaction, while the shelter space was not functionally visited due to the influence of minimizing visibility, social interaction, and arrangement of attribute elements.
\end{abstract}

Keywords: Activities patterns; group visitors; public open space; transit space

\section{Introduction}

Public open space at this writing is an open space that is able to accommodate the need for meeting places and joint activities in the open air. This space allows a meeting between humans to interact with each other [1]. They carry out various activities in a visit including sightseeing, meetings, transit, taking pictures, deliberation, public open space occurs because of the need for a city space so that it can accommodate all visitor activities on a visit to enjoy Makassar City facilities. The Losari beach pavilion is a public open space that has been known as a city icon, attracting the attention of visitors that come from within and outside the city. The type of group visitor emphasizes the activities that occur so that events can be seen at each stopover.

In the design of this public open space, especially in the space configuration, parts of the space have been designed functionally as a space for visitors to stop by. The space that

\footnotetext{
${ }^{\star}$ Corresponding author. Tel.: +62811 4136880

BTN Tabaria, Makassar, Sulawesi Selatan Indonesia
}

has been provided as a shelter space is not all used by visitors in its function, even some shelters accommodate overlapping activities so as to create unoccupied space in the sense that space is not functional in this case by Carr [1] argues that public open space is a public area where people doing ritual activities and functional activities that overlap should be avoided. Thus the importance of minimizing these incidents is also for social equality for visitors to the space configuration that has been planned functionally.

Project for Public open spaces (PPS) stated in a handbook for creating successful public open spaces that they find four key qualities of a successful public open space from its 1000 studies on public open space, one of which is "uses and activities". Activities or space allotment are the basis of a place to have something to do and give people a reason to come and come back to this place again. When there is no activity, space will be empty and generally, this means that something is wrong and wrong [2] and "Sociability" This is a quality that is difficult for any place to achieve but once it is successful it will become a clear feature. When people see colleagues meet and greet each other and feel comfortable interacting with others, they will tend to feel the enthusiasm of one space to gather with their 
group so that it becomes a place that fosters types of social activities [2].

Some of the conditions described and opinions according to experts related to the issues raised became the focus of research. The purpose of this problem is to find and reveal what effects there are on the transit space to stop by and the occurrence of unoccupied space on group visitor activities, the meaning in this case, is not used as a spatial function so that it is useful for the consideration of the developer of the Losari Beach Pavilion in Makassar City and hopes that it can be the basis for the design consideration of space configuration in public open spaces.

\section{Literature Review}

The systematic variables of this study reviewed several studies namely public open spaces and the activities/behavior of visiting people

\subsection{Public open space}

Carr invites us to see people's need for public open space as a means of interaction and the public open space that is most interested in society, in general, is the circulation route because it has dynamic values so that it is not boring [3].

Public open space is also articulated by Hanna Arendt into two dimensions, that is the space of appearance and the world together The apparition space is a public open space that humans use to show who they are in front of others. The shared world space is a life that is shared among other human beings like a table among those who sit around it [4]. The public sphere can collapse under conditions such as radical isolation and mass hysteria Radical isolation where everyone no longer gives mutual consent and private desire to opt for public open space. The mass hysteria of everyone suddenly acting as if they are part of a family, they duplicate the values or perspectives of members of the family [5].

Belief in the point of view of the main value of the public open space, that is that there are three things that are responsive, democratic, and meaningful. Responsive in the sense of public open space is a space that can be used for various activities and broad interests that have environmental functions. Democratic means that public open space can be used by the general public from various social, economic and cultural backgrounds as well as access to various human physical conditions. Meanwhile, it means that public open space must have a link between humans, space, and the world at large and the social context. In other words, there is a system of meaning in the public open space [3].

According to Hantono, there are two forms of public open space, that is Elongated (the street), which is a space that has a longer dimension on both sides than the other. Space shaped like this has a tends to form a linear, one-way, parallel circulation pattern. In general, public open spaces that have this form are roads, rivers, corridors, and others. The square, which is a space that has almost the same dimensions on all sides, has a tends to form circulation patterns in all directions, random, organic. In general, public open spaces like this take the form of fields, parks, and so on [6].

Characteristically, both have the same geometric shape, but what distinguishes them is the function and circulation patterns. And these two basic forms interpret public open spaces, both closed and open, especially in the public open space of the Losari beach pavilion, including in the elongated basic form, therefore it tends to have a pattern of visiting activities that occur.

\subsection{The activities of group visitors}

a. Activities

The meaning of activity in a space can be divided into three kinds of activities, according to Zhang and Lawson [7], that is:

- Necessary activities, namely routine activities carried out because of an obligation to fulfill a certain need. A good environment is an environment that can accommodate and accommodate all types of activities needed.

- Optional activities, namely activities carried out when there is an opportunity or the right time. Usually, these activities are carried out in a pleasant environment and there are no other more pressing activities.

- Social activities, namely activities that involve interaction with other parties around them. These are because of the planned main activities and optional activities because there are main activities and optional activities.

Passive involvement and active involvement in public open space utilization activities occur as a result of this interaction process (Necessary, Optional and Social), where users of public open space can interact in different ways. Space as a place must be able to provide a conducive environment for the fulfillment of interaction requirements, namely opportunities for social contact and communication. Social interaction can occur in the form of passive activities such as sitting enjoying the atmosphere or situation and can also occur actively by talking with other people discussing a topic or even doing activities together according to Carmona [8].

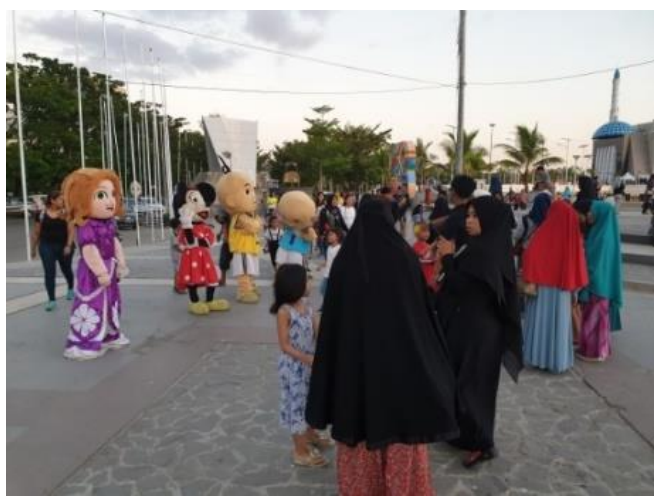

Figure 1. Entertainment can increase the vitality of space to visitor activities 
Gehl [9] revealed that visitor activities attract other people and as a public open space it can attract other people as well because of something that is done in it if there is something to be done people want to spend time in public.

\section{b. Group behavior}

Humans are the center of the environment as well as being part of the environment. An individual interacting with space is influenced by the atmosphere of the space and affects the atmosphere of that space. Behavior can be defined as part of the interaction process between human personality and the environment. The environment contains stimuli (stimuli) which are then 'rewarded' with responses by the personality, one of which is behavior [10]. The reciprocal relationship between atmosphere and behavior is also influenced by design factors and the dominant characteristics of the humans who interact in it. The quality of the environment is formed because the spatial atmosphere sensed by humans becomes a perception that is reflected in human behavior, on the other hand, human activities or behavior itself can affect the atmosphere of space, [9].

The word behavior shows humans in their actions, relating to all human activities physically in the form of human interactions with each other or with their physical environment. On the other hand, architectural design will produce a physical form that can be seen and can be held. Therefore, the results of architectural design can be one of the facilitators of behavior, but can also be a barrier to behavior [11]. Meanwhile, Whyte said that the behavior of urban public open space users in America can be influenced by several factors using open space, including seating, sunlight, wind, vegetation, water, food, direct physical and visual access to the main road [12].

The behavior of the people who interact and hang out forms a group as well as the behavior of visitors at the Losari Beach Pavilion, directly or indirectly related to elements of "sociology", "psychological" and "environmental psychology". Because of that, there is a reciprocal relationship between public open space and visitor behavior by seeing it in an interrelated state and not standing alone. In terms of the relationship between the use of facilities that have been designed with behavior that tends to be created in the public open space.

Human behavior is shown in the nature of a person and how that person adapts to the environment around him. The adaptation that humans make to architecture creates a meaning or more that can be seen by everyone to cover the needs of human life. Human behavior is identified by observing human behavior based on the meaning of someone doing these activities.

\section{Research Methods}

This type of research is qualitative. This type of research is inductive [13]. This is inductive because at the beginning of the observation it collects field data and concludes the statements of the results of the observations in a statement that is more general and characterized by empirical sciences.

This research method uses the behavior mapping method because with this method you can get detailed activities in the form of a behavior map in each group of visitors. One of the mapping based on the actor (person-centered mapping) this technique emphasizes the movement of humans over a certain period of time [14]. This technique is concerned with not just one place but several places. The researcher deals with a person or group that is specifically observed. The step taken is to follow the activities carried out by group visitors by recording, sketching, and making notes on the base map.

The data analysis carried out in this study approached an empirical study. Empirical is also research whose nature is exploring (explorer), describing (descriptive) and also explaining (explaining) [15].

The object of research is group visitor activity in the public open space of the Losari Beach Makassar Pavilion, starting from the beginning of arrival to the end of the visit and leaving the research location, this results in the overall results of the activity to be able to see what influences are in each room and activity. Presentation of the analysis results in the form of a table matrix, activity map images and description explanations. This presentation produces answers to the problems that occur.

The public open space that is the object of research is in South Sulawesi Province, Makassar City, Penghibur Street, right in front of Datuk Museng Street and Maipa Street. This pavilion faces westward so many visitors come to see the sunset.

Sources of research data are taken from two sources:

a. Primary sources are observations, interview results, sketch results and video recordings of visitor activities. Observations were made on two platforms located between the entrance and exit doors, namely the Makassar Bugis Pavilion and the Losari Beach Pavilion. Interviews were conducted with 30 groups of visitors and activity sketches and video recordings were carried out on 20 groups of visitors at busy times, namely $16.30 \mathrm{WIB}$ - 22.00 WIB on Fridays and Saturdays.

b. Secondary sources are research supporting data from related agencies such as regional planning offices, books related to research titles, and publications that support research.

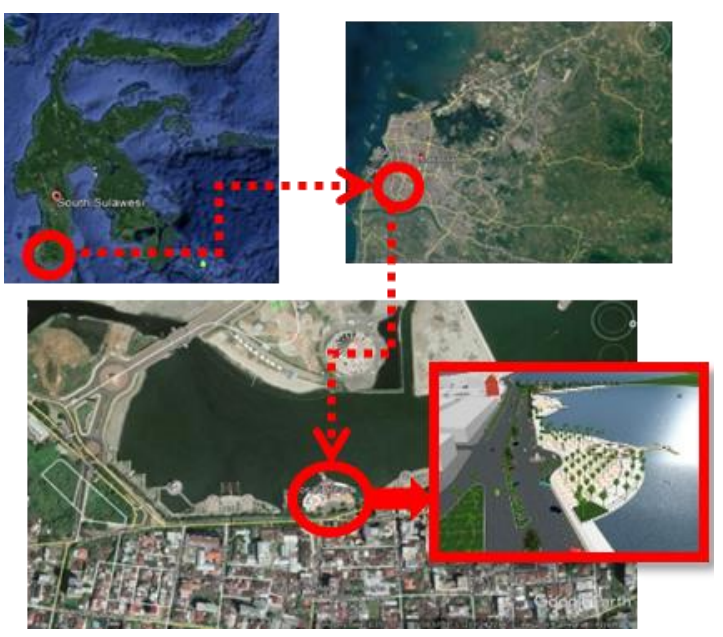

Figure 2. Losari beach pavilion location 
In connection with the research method used is behavior mapping by means of sketching, describing, recording, recording the activities of the actors of the research object, research instruments, namely:
a. Research team
b. Base map image
c. Stationery
d. Smartphone
e. Interview module

The validity technique used in this research is the credibility test by means of the triangulation of the technique of reanalyzing the results of the interview and then matching them with the results of observations and documentation so that the results of the triangulation of this technique obtain the same or valid data. The next test tests the reference material that the reference shows the results of interviews, recorded data sources, field photos and documentation tools so that it can be stated to support the credibility of the data and testing of increased persistence is done by checking all data collection techniques from initial to final observations so that the data found to provide accurate and systematic descriptions thereby increasing the credibility of the data.

\section{Results and Discussion}

\subsection{Research results}

a. Makassar Bugis Pavilion and Losari Beach Pavilion The Losari Beach Pavilion is a beach located west of Makassar City, right in the heart of Makassar City on Jalan Penghibur, where various activities take place there. Losari Beach is a public area for the community and is one of the icons of Makassar City. Geographically, Losari Beach, Makassar City is limited by the coordinates $119^{\circ} 22^{\prime} 42^{\prime \prime}$ $119^{\circ} 24^{\prime} 38^{\prime \prime}$ East Longitude and 05 07'36 "- $05^{\circ} 08^{\prime} 54^{\prime \prime}$ LS. Administratively, Losari Beach is bordered by Jl. Somba Opu and Makassar Golden Hotel (North side), Jl. Entertainers, commercial buildings, residential areas and Stella Maris Hospital (East Side), Tanjung Bunga Metro Area (South Side) and Makassar Strait (West Side). The public open space of the Losari Beach Pavilion consists of 3 courts, namely the Makassar Bugis Pavilion, the Losari Beach Pavilion, the Toraja Mandar Pavilion with a length of more than $800 \mathrm{~m}^{2}$.

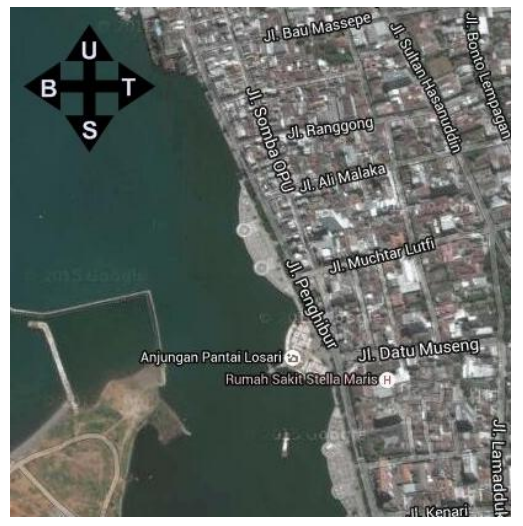

Figure 3. Losari beach area, (www.google.earth.com)

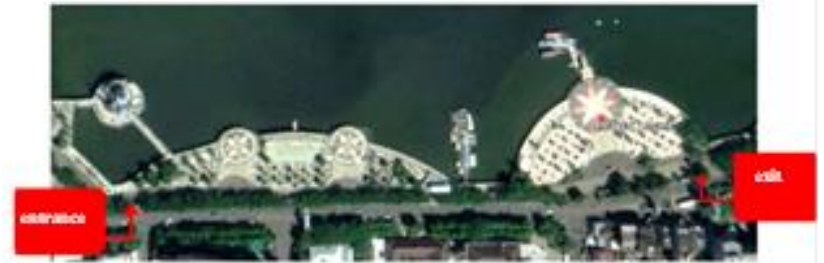

Figure 4. Research location limitation (www.google.earth.com)

From the observations of the activity observations on the three platforms, there are only two platforms that have the potential for group visitor activity patterns, including the Makassar Bugis Pavilion and the Losari Beach Pavilion which are supported by their existence between the entrance and exit distance, while the Mandar Toraja Pavilion has become a traditional culinary area and There is no potential for a pattern of activity in public open space visits so that only two platforms were chosen for the boundaries of the research location.

\section{b. Group visitor activity pattern}

The Losari Beach public open space is one of the city's icons that is attractive to be visited by both local people and migrants. Since the first construction of this element, the letter statue with the inscription "Pantai Losari" has been recognized by people both inside and outside Makassar City. Visitors who come are not a few from out of town. The visitor category is also the majority of group visitors to enliven this public open space. The condition of visitors is not experiencing density every day where this study looks for the dense time of visits so that it can provide real results from Monday to Sunday, only weekends experience visitor density, namely on Friday, Saturday and Sunday. Friday and Saturday between 16-30 and 22-00.

Of the total group visitors, 20 groups were taken to become participants with a different number of group personnel, of the 20 groups totaling 153 visitors and the categories of visits were divided based on the number of visitors.

- Friday at 6:00 p.m. local time, there were 3 groups $(6,5,5)$ people, the rooms that were visited were the Makassar Plaza (1), the stage (3), the Bugis Plaza (2), in front of the Bugis Plaza, the seats (7a), (7c) and Losari Beach Plaza (6).

- Friday at 19.00 WITA there were 5 groups $(8,9,8,9,10)$ people, the rooms that were visited were the Makassar Plaza (1), seats (4a), (4b), and Losari Beach Plaza (6).

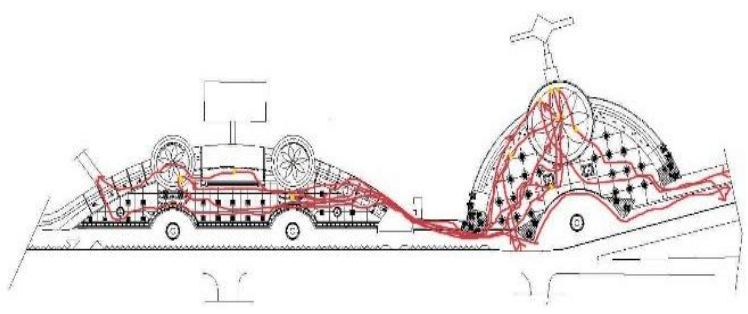

Figure 5. Finding the travel patterns of group visitors based on (day and time) Friday at 18.00 WITA 


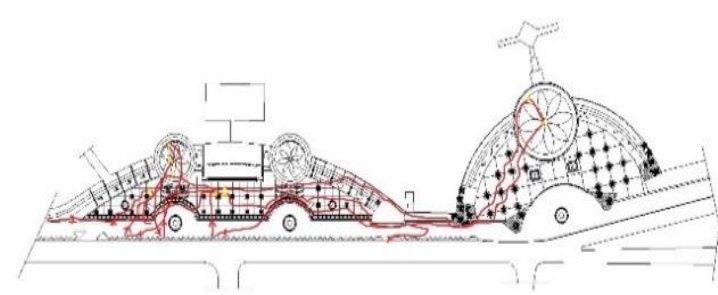

Figure 6. Finding the travel patterns of group visitors based on (day and time) Friday at 19.00 WITA

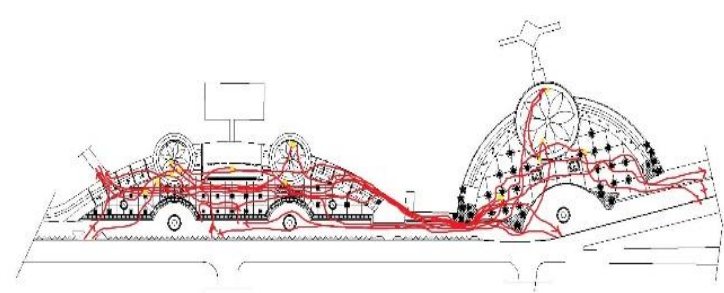

Figure 7. Finding the travel patterns of group visitors based on (day and time) Saturday at 18.00 WITA

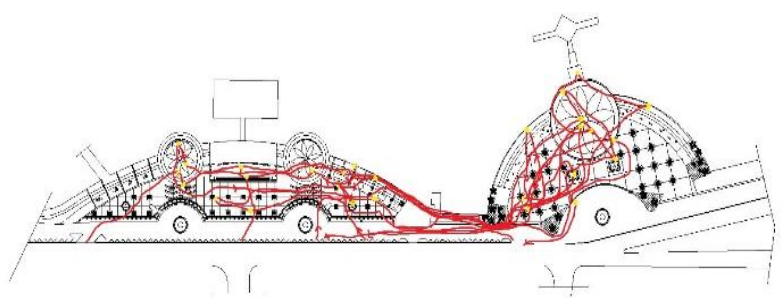

Figure 8 . Finding the travel patterns of group visitors based on (day and time) Saturday at 1.00 WITA

- On Saturday at 18.00 WITA, there were 6 groups $(5,5,7,7,10,4)$ people, the rooms that were visited were the Makassar Plaza (1), the Bugis Plaza (2), the stage (3), the seats (4a), and Losari Beach Plaza (6), seats (7a), (7b).

- Saturday at 19.00 WITA there were 6 groups $(8,11,11,13,5)$ people, the rooms that were visited were the Makassar Plaza (1), the Bugis Plaza (2), the stage (3), the seats (4b), (4c), (7a), (7c), (7d), the statue area (5), the Losari beach plaza (6), and the Adipura monument (8).

Table 1. Activity type coding

\begin{tabular}{|c|c|c|c|}
\hline No. & Type of activity & Coding & The meaning of activity \\
\hline 1 & Sit back & 0 & optional activities \\
\hline 2 & Tell stories, talk & & $\begin{array}{c}\text { necessary activities, social } \\
\text { activities }\end{array}$ \\
\hline 3 & Played & O & optional activities \\
\hline 4 & $\begin{array}{l}\text { Photo with public } \\
\text { art and elements }\end{array}$ & $\mathrm{C}$ & $\begin{array}{l}\text { necessary activities dan } \\
\text { social activities }\end{array}$ \\
\hline 5 & Group photo & 0 & $\begin{array}{c}\text { necessary activities dan } \\
\text { optional activities dan social } \\
\text { activities }\end{array}$ \\
\hline 6 & Waiting & ? & necessary activities \\
\hline 7 & Stand relaxed & C & $\begin{array}{l}\text { optional activities dan social } \\
\text { activities }\end{array}$ \\
\hline
\end{tabular}

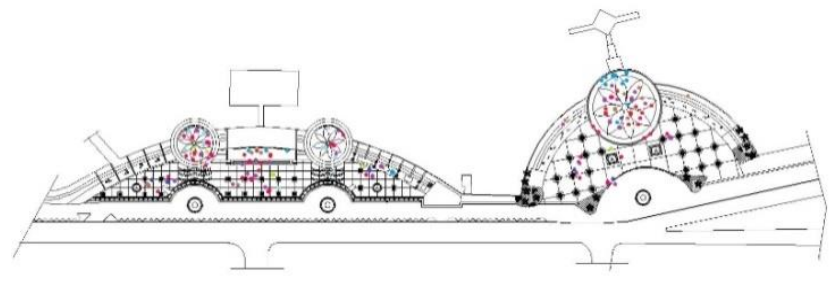

Figure 9. Mapping activity types

Description:

$$
\begin{aligned}
& : 29 \text { activities } \quad: 17 \text { activities } \quad: 20 \text { activities } \\
& : 38 \text { activities } \quad: 11 \text { activities } \\
& : 6 \text { activities } \quad: 12 \text { activities }
\end{aligned}
$$

From the analysis of the activity patterns of group visitors who carry out visiting activities from the entrance to the exit, there are 6 types of activities that occur in the convex space, from coding activities, it can be seen that an assessment of what types of activities occur the most.

The meaning of activities in a transit space, there are three categories of activities, namely necessary activities, which are the main activities such as waiting for stories, talking, group photos, photos with public art and elements, optional activities, which are optional activities such as playing, sitting and standing, and social activities which are activities such as chatting, talking casually, taking pictures with public art or with groups and standing up to casually having a look. Analysis. In the activities that occur at each stopover, there are 7 types of activities carried out in groups [7].

\subsection{Research discussion}

a. Analysis of the Parts of Space

Both of these pavilions have spaces that become transit points where this is used by visitors to an interesting spot or space to stop by and this pavilion also has an arrangement of elements. The transit points are shown in Fig. 10.

- Makassar Plaza Roundabout (Fig. 11)

This space has dimensions of $21.4 \mathrm{~m}$ in diameter plus a trap width of $1.7 \mathrm{~m}$ and $2 \mathrm{~m}$ with a total diameter of $25 \mathrm{~m}$. The area that is owned gives the impression that it is free to make visitors stop just to stand back and sit down to rest for some time.

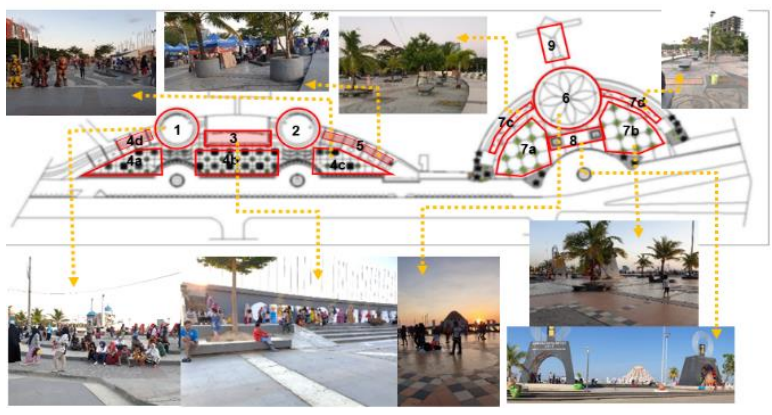

Figure 10. Division of transit Space 


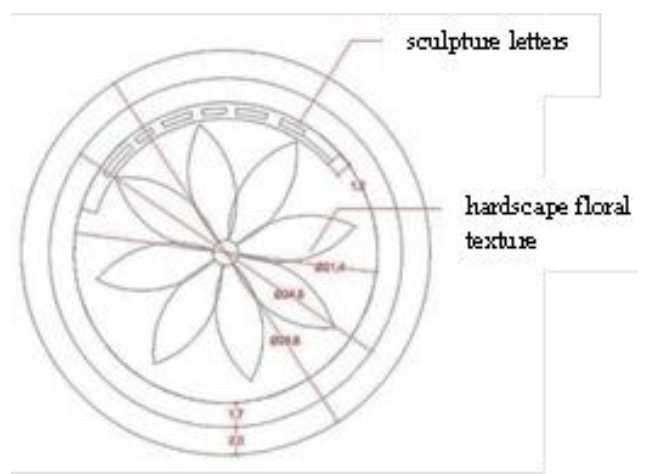

Figure 11. Transit space specifications (1)

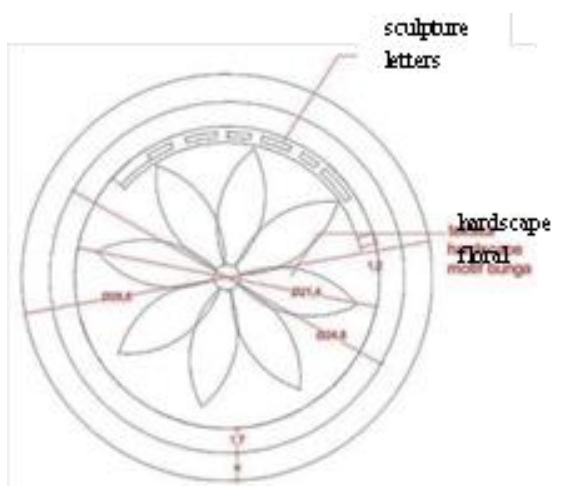

Figure 12. Transit space specifications (2)

This space is equipped with the property elements of a letter statue with the words "Makassar". Each letter is about $30 \mathrm{~cm}-70 \mathrm{~cm}$ high, $2 \mathrm{~m}$ high red letters with sea views up to the planning area of the Center Point Of Indonesia. The hardscape is patterned with flowers with the material used in the form of natural stone for outdoor so that from its durability it can face rainy and dry seasons.

- Plaza Bugis Roundabout (Fig. 12)

This plaza has dimensions and hardscape and the same shape as the Makassar roundabout plaza. (1) The only difference is that the letter statues that read "Bugis" are sculptures of Makassar and Bugis letters.

a) Stage (Fig. 13)

This space is a platform like a stage for City event activities with dimensions of $40 \mathrm{~m}$ long and $7.7 \mathrm{~m}$ wide. The blocked stairs are planned for the development of the next stage, just like the roundabout plaza.

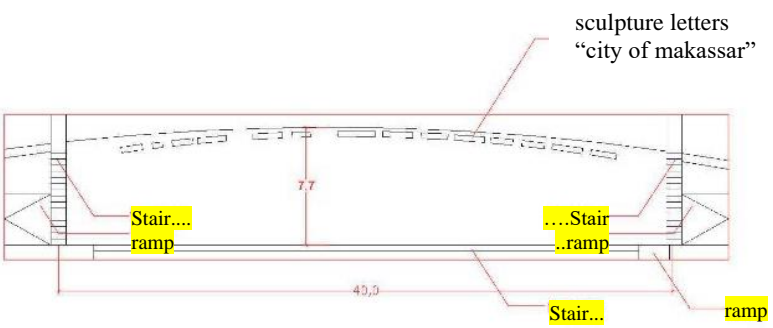

Figure 13. Transit space specifications (3)

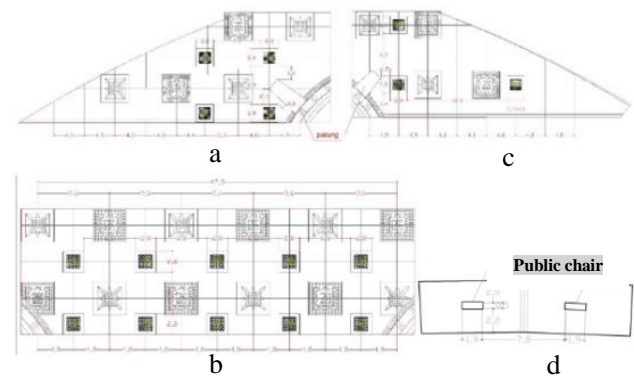

Figure 14. Transit space specifications (4a, 4b, 4c, 4d)

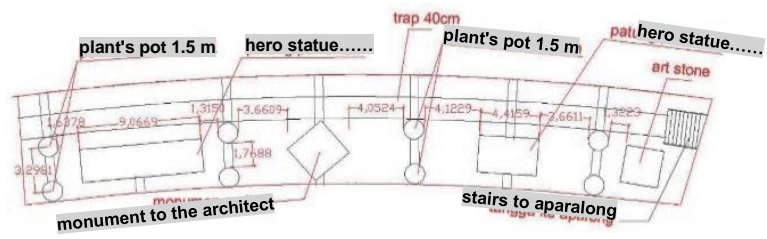

Figure 15. Transit space specifications (5)

It also has a letter statue with the words 'city of Makassar' 2 meters high, $30-60 \mathrm{~cm}$ in white, visitors use this space to stop taking photos with the object of a letter statue with white color making elements It gets dirty quickly and reduces the aesthetic value of the existing public art area as well as choosing this place as a stopping point for offering photo property services.

b) Seating area (a, b, c, d) (Fig. 14)

Visitors to this seating area are not as busy as visitors who stop in areas (1), (2), and (3). All permanent concrete seats are in a rectangular shape measuring $2.8 \mathrm{mx} 2.8 \mathrm{~m}$ with a plant arrangement in the middle measuring $1.8 \mathrm{mx} 1.8 \mathrm{~m}$, the distance between the seats is $5 \mathrm{~m}-16 \mathrm{~m}$ and other forms of seating are rectangular with a size of $1.9 \mathrm{mx} 0.5 \mathrm{~m}$ and a material floor natural stone combination tiles. The capacity of people to sit in rectangular seats per one unit is 27 people, this capacity is enough to accommodate 2-3 groups per one seat and the rectangular seating capacity for 4-5 people accommodates 1 group while the number of rectangular seats is 17 units and a 2 unit rectangle.

c) Sculpture Area (Fig. 15)

The area of the statue is a space that is located in the position of the connecting access between the two platforms, this area is often crowded with visitors because of the narrow connecting route and becomes a stopover point. Group visitors who pass through this area feel uncomfortable with the traps up and down the surface level of the space for movement or the hallway between the statue properties.

d) Losari Beach Plaza (Fig. 16)

This room is the room that has the highest level of visits from the first 20 groups of roundabout plazas built in this area. A letter statue is also available in this plaza with a display of "Pantai Losari", a letter height of $2 \mathrm{~m}$, the distance between letters $30-40 \mathrm{~cm}$ in white. 


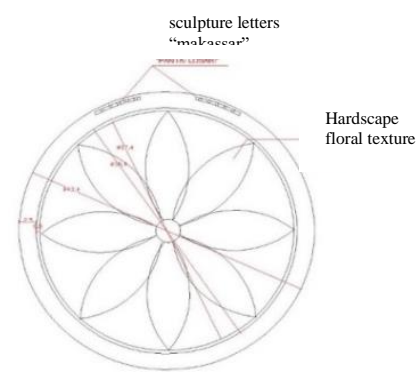

Figure 16. Transit space specifications (6)

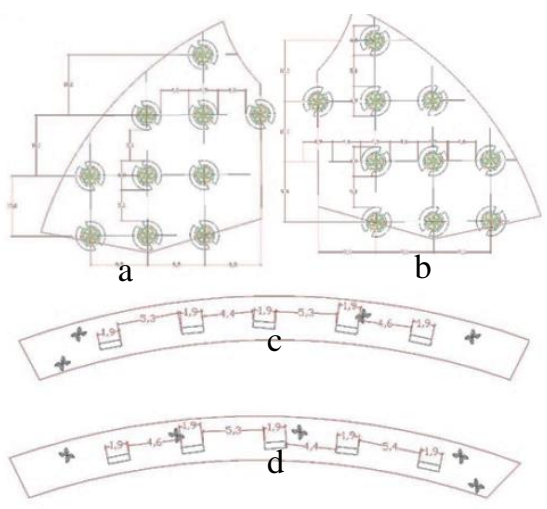

Figure 17. Transit space specifications (7)

This letter statue is what is known by the immigrant visitors. Not a few visitors come with the aim of taking photos as a backdrop of this element. The plaza with a diameter of $37.4 \mathrm{~m}$ plus a trap dimension of $0.5 \mathrm{~m}$ and $2.5 \mathrm{~m}$ made of natural stone with floral motif tiles.

e) Seating area (a, b, c, d) (Fig. 17)

This space is designed as a place to sit, rest, relax. This seating area is available in 4 areas, but out of the 20 groups who visited, only 1-4 visitors stopped to use this space. Seats in a circular shape measuring $5 \mathrm{~m}$ in diameter and in the middle are provided a plant pot with a diameter of $2.5 \mathrm{~m}$, the capacity of people to sit per one unit is 24 people, accommodating 1-2 groups, while the long rectangular seat measuring $1.9 \mathrm{mx} 0.5 \mathrm{~m}$ has a capacity of 5 people per one unit. 1 group. The number of circular seats is 20 units in areas $7 \mathrm{a}$ and $7 \mathrm{~b}$, while areas $7 \mathrm{c}$ and $7 \mathrm{~d}$ are elongated as many as 10 seats in the area where vegetation is available as protection, but the condition of small vegetation does not protect all seats.

f) Adipura monument (Fig. 18)

This room is the area of the Adipura trophy monument. The first monument is the Adipura monument in the small town category, which was won during the leadership of Malik B Masri in 1997.

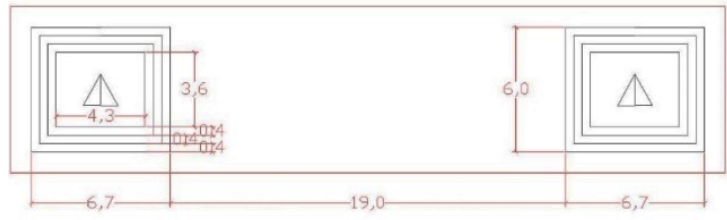

Figure 18. Transit space specifications (8)

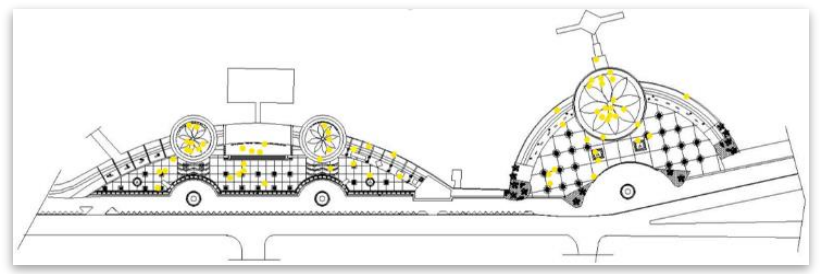

Figure 19. Stop point for group visitors

The second monument is the Adipura Cup in the metropolitan city category which was won under the leadership of Ilham Arief Sirajuddin in 2013. Then these two pillars were put together at the Losari Beach Pavilion placed in front of the Bundara plaza These two monuments are designed in the form of a tunnel that functions as a shelter for visitors who want to take shelter under it during the day and are equipped with spotlights in the tunnel from the lower corner at night as well as abstract motifs on the walls to add to the beauty of the photos. The distance between the two monuments is about $19 \mathrm{~m}$ and a height of about $10 \mathrm{~m}$ attracts visitors to capture the moment of their visit and stop in this area.

The image of the display of transit points in group activities of 20 visitors in the transit space is shown in Fig. 19. The Losari Beach Pavilion Plaza gets the largest number of visitors to stop by for a moment, supported by the good spots this space has in terms of visualizing sea views, size, location and more elements. wider and larger dimensions than other plazas, the plaza is located in the center of 3 pavilions coupled with the availability of the property of the "Pantai Losari" letter statue that has become an icon of public open space in this city which attracts visitors.

Table 2. Transit space for group visitors

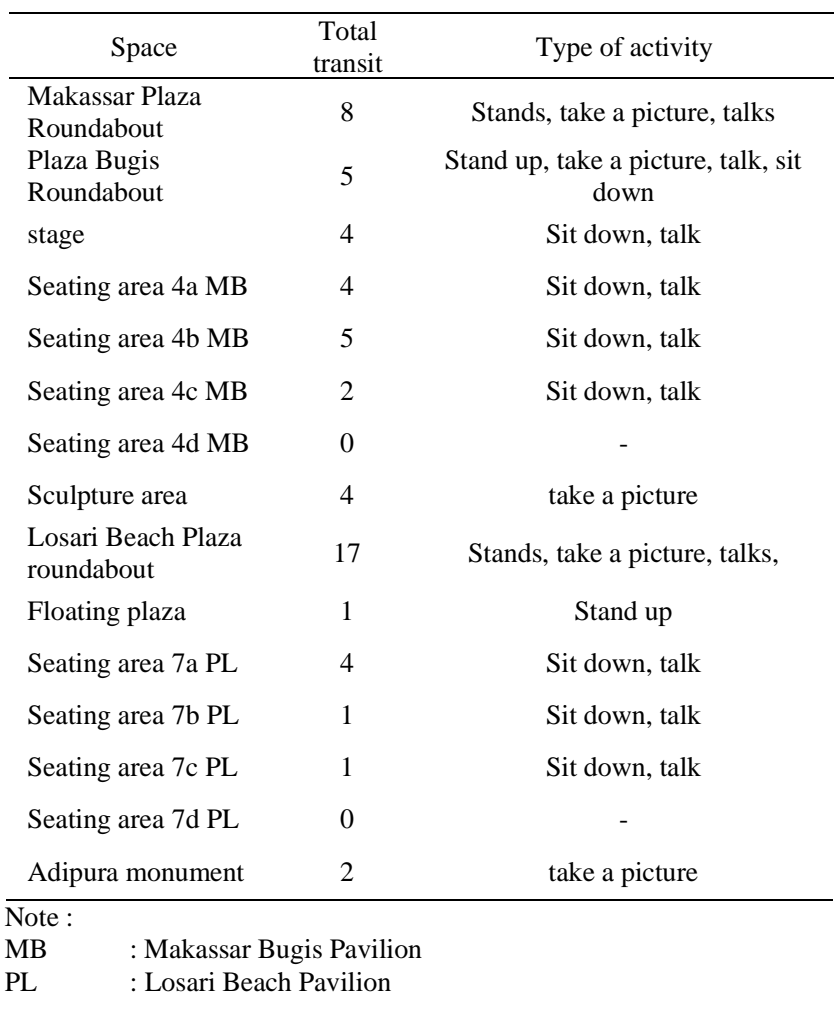




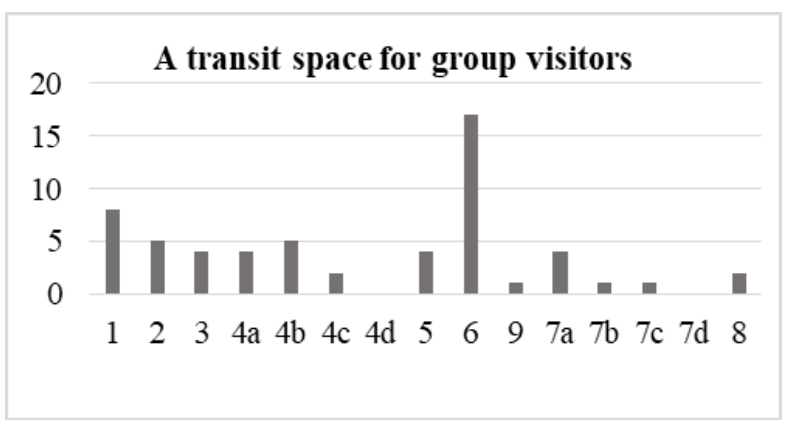

Figure 20. A diagram of the size of the transit point in the transit space

In some spaces that are always a place for visitors to stop by, they are equipped with elements as a property for completing photos, in this case, it is clear to get a good spot as one of the goals of visitors besides just taking a walk is to take a moment by taking pictures.

\section{Conclusions and Recommendation}

\subsection{Conclusions}

The conclusion of this study is based on the results and discussion of research showing and finding the effect of shelter space on group visitors who are escorted by several theories for the process of this research. These influences are as follows:

a. Influence on transit space which causes activities to overlap

1) Spatial area is a space that has an area without any buildings above it so that in terms of taste, it is able to give the impression of being plong when stopping to carry out various activities.

2) Visibility is a situation that is owned by the space that attracts visitors to stop by to enjoy the view while doing various activities

3) Historical area is an impression of historical traces that have settled in a space and can be felt by visitors.

4) Iconic elements, an arrangement of attributes, which the property offers to capture the moment of visit.

5) This social interaction is an activity that is quite influential for visitors to stop by and increases the vitalization of space.

b. The influence of space that has been designed to be a shelter does not appear to be functioning in its function, it is influenced by the minimization of visibility, internal space, social interaction, attribute and building elements such as seating do not affect visitors because they stop by to sit, rest, tell stories. carried out anywhere that makes visitors fit to stop by to do these activities including spaces that have been discussed from the research results.

c. The effects that are obtained make visitors do activities simultaneously and all visitors want to feel it so that there is overlapping activity.

\subsection{Recommendation}

From the conclusion statement, there are several recommendations which are:

a. Maintain the influence that has been obtained and then developed and that influence is implemented in the that occurs, the unoccupied space that is meant is the space where there is minimal visiting activity.

b. By cultivating the effects that the existing overlapping activities can spread and minimize the occurrence of unoccupied space.

\section{References}

[1] S. Carr, M. Prancis, G. Rivlin, L, and M. Stone, A, Enviroment and Behavior Series Public Space. America: Cambrige university press, 1992.

[2] Project for Public Spaces, How To Turn A Place Around, A Handbook For Creating Successful Publik Spaces. New York, United States Of America, 2008.

[3] M. P. D'Entreves, Filsafat Hannah Arendt. Yogyakarta, 2003. [in Bahasa]

[4] D. Hantono, "Pattern of Public Open Space Activities in Fatahillah Park Area," J. Arsit. Komposisi, vol. 1, no. 1, 2017. [in Bahasa]

[5] D. Hantono, Y. F. D. Sidabutar, and U. I. M. Hanafia, "City Public Space Study Between Activities and Limitations," Langkau Betang J. Arsit., vol. 5, no. 2, pp. 80-86, 2018. [in Bahasa]

[6] D. Hantono, "Behavioral Studies in Public Open Space," NALARs, vol. 18 , no. 1, pp. 45-56, 2019. [in Bahasa]

[7] Zhang and Lawson, "Activities in Publik Outdoor Spaces Outside Highdensity," urban Resid. communities. Urban Des. Int., 2009.

[8] M. Carmona, T. Healt, T. Oc, and S. Tiesdell, Publik Place-Urban Space:The Dimention of Urban Design. Tokyo: Architectural Press, 2003

[9] J. Gehl, Life between Buildings: Using Publik Space. Washington DC: Island Press, 2011

[10] T. Hidjaz, Interior Design and Visitor Behavior in the Kelapa Gading Mall Public Space Case. Bandung: National Institute of Technology. [in Bahasa]

[11] J. M. Laurens, Architecture and Human Behavior. Jakarta: PT. Grasindo, 2005. [in Bahasa]

[12] H. W. Whyte, The Social Life of Small Urban Spaces. New York, 1980.

[13] Sugiyono, Research Methods Combined (Mixed Methods). Bandung: Penerbit Alfabeta, 2017. [in Bahasa]

[14] H. R. Agustapraja, "Pedestrian Behavioral Mapping Study on Pedestrians in Lamongan City Square,” Islamic University, 2018. [in Bahasa]

[15] H. Hadikusuma, Methods of Making Working Papers or Legal Thesis. Bandung: Mandar Maju, 1995. [in Bahasa] 